\title{
Dance Online Learning for Children with Special Needs
}

\author{
Made Utami Trisna Dewi ${ }^{1}$ Kusnadi $^{2}$ \\ 'Graduate School of Art Education, Yogyakarta State University, Yogyakarta, Indonesia \\ ${ }_{2}^{2}$ Graduate School, Yogyakarta State University, Yogyakarta, Indonesia \\ Corresponding author.Email: madeutamitrisnadewi@gmail.com
}

\begin{abstract}
This study aims to examine how dance education online learning to students with special needs is conducted. This is qualitative research in which the participants were children with special needs and the formal object was the children's creativity development. The subjects of this research were teachers in the Nalitari community in Yogyakarta. The instrument in this study was the researchers themselves. The data of this research were collected by means of observation guides, interview guides, and documentation. The results showed that the children's creativity is developed. The development covers eight aspects, namely (1) physical, (2) perception, (3) thinking skill, (4) emotional, (5) creativity, (6) social skill, (7) aesthetic sense, and (8) talent.
\end{abstract}

Keywords: Improving creativity, dance, children with special needs

\section{INTRODUCTION}

Creativity is basically the ability to invent things that have never existed before. Creative activity has a fundamental role and is needed to shape a child's personality. Lowenfeld argues that art and creativity are strong beliefs so that in the implementation of art education, aesthetic experiences and creative activity are all important. [1] Beside being able to enrich children's mental/inner experiences, creative activity is able to develop children's creativity. With experiences, skills, and imagination, children are expected to act, interpret, organize, and even create something new using a new strategy which leads to different results from what they usually experience daily. Using this strategy, they may become more open, creative, and humane.

Creativity is an attempt to express basic characteristics through a form or medium in such a way as to produce a sense of satisfaction for oneself. Creativity produces a product that represents the creators to other people. It is a new product of imagination. Creativity includes four stages of the process, starting from preparation, incubation, illumination, and verification. [2] Through the four stages of this process, students will be motivated and enthusiastic to create something.

Physical exercise is a human activity to move the body. Exercise trains physical endurance, muscle endurance, bones, and breath. Breathing and movement coordination are important for dancers, so the dancers should have balance abilities. The balance of breath and motion produces strong expression and strength. Physical exercises are also useful for training a dancer's attitude. This attitude works for attracting audiences and give some kind of energy to the stage. Bodies that are used to move will easily express what in the mind is so that they can provide quick actionreaction and interactions. In addition, it can provide sensitivity effects for objects or subjects.

Dancing is the process of moving from one posture to another. Dance movement can be defined as a visual reality. [3] Dance is an expression, a statement, an expression in motion and contains comments on the reality that remains in the audience's mind after the show is over. [4] In order to be able to produce harmonious movements, correct physical exercise should be conducted. In terms of physical exercise, there are two types of movements in dancing, namely pure movement and gesture. Pure movement is the result of the processing of the wantah motion, so it does not contain meaning but contains aesthetic values. Meanwhile, although gesture also contains wantah motion, it goes through a process that results in meaningful movements with aesthetic values.

Children with special needs have unique physical, mental, and emotional development. According to Sabra, generally children with special needs are 
provided with special education. Educational services provided for children with special needs are regulated under the Minister of National Education Regulation Number 70/ 2009. The government has initiated inclusive education to provide an educational service system for children with special needs so that they can study together with other children in the same school. [5]

Inclusive education puts great emphasis on human rights, for both normal children and children with special needs. Inclusive education has the basic principle that wherever possible, all children should learn together regardless of the difficulties or differences they may have. Inclusive classes consist of children and children with special needs. According to Hidajat that teaching and learning activities in an inclusive class are not much different from teaching and learning in regular classes in general. The portion of learning in an inclusive classroom is more flexible because the teacher adapts to the abilities of students with special needs. [6]

The Covid-19 pandemic has forced millions of students to study at home but still requires them to express themselves actively, creatively, and productively. All children including those with special needs should adapt to the condition. The online learning system is an internet-based interactive model and Learning Management Systems (LMS) such as Zoom, Google Meet, etc.

The Covid-19 outbreak greatly affects children with special needs because they have limited access to do the daily activity and to interact with other people. Thus, in order to channel the emotion, online learning is done. Online physical education may improve children's creativity independently. Through this study, researchers intend to facilitate children with special needs with an activity to improve their creativity and productivity during the Covid-19 pandemic.

\section{RESEARCH METHOD}

This research is entitled "Dance as Online Physical Education for Children with Special Needs". This qualitative research aimed to examine the phenomena experienced by the research participants. Their behavior, perception, motivation, and action were described holistically in a special natural context by utilizing various natural methods. [7]

This research employed the descriptive qualitative approach. The main instrument in this study was the researchers themselves. In collecting data, researchers are guided by observation guides, interview guides, and documentation study guides. In addition, the validity of the data was obtained by means of data triangulation.

\section{RESULT AND DISCUSSION}

\subsection{Children with Special Needs}

Nalitari community in Yogyakarta is a nonprofit organization that aims to raise issues of equality and inclusiveness through dance. Dance Ability a method created in 1987 by Alito Alessi, an American dancer who has been active for 30 years. Dance Ability uses improvised dance methods to express artistic values and to unite exploratory movements between people with and without special needs.

Nalitari Community has become a medium of communication and learning space for people involved to explore artistic movements together and further build an inclusive community, a community without segregation. The vision and mission of the Nalitari community is to become a community that maintains freedom in exploring and expressing and respects differences and diversity.

In Nalitari community, children with special needs have needs which are physically, mentally, and psychologically different. The community serves as a place where children can have the same position as other people or other groups so that the children special needs can understand other people's perspectives. From an inclusive understanding, Nalitari community wants to make children understand that everyone looks special and is indeed special.

\subsection{Physical Exercise for Children with Special Needs through Online Learning}

Dance can be said to be something that is closely related to human life because it is a social activity carried out by many people of various ages and in various places. Dance is an aesthetic expression in movement. It is a very unique way to express creativity. Dancing may develop tolerance, democracy, and a virtuous personality.

Online Learning is an interactive internetbased model. Children in Nalitari community are not able to come to get dance lessons during the COVID-19 situation. Thus, they get online lessons. Dance trainers in Nalitari community use the Online or Virtual method to give the children an understanding that dancing can be done anywhere, anytime, and based on any theme. The trainers provide material and examples of dance in a 1minute video. The children then can practice it freely by exploring their ideas/imagination, creativity, and emotions.

Physical activities (dancing) cover various areas of development because dance is not only composed of elements of motion (kinesthetic intelligence) but also has rhythm (musical intelligence) and uses movement and floor patterns (visual-spatial intelligence), which can be performed in groups or individually (intrapersonal 
intelligence and interpersonal intelligence). This dance activity consists of rhythmic and dynamic beats (mathematical logical intelligence), and it is performed in accordance with the environment theme (natural intelligence). Likewise, dance uses nonverbal language or movement to convey something to other people (linguistic intelligence). If done properly and correctly in offline or online dance lessons, this dance can develop children's intelligence holistically.

Read stated that art education functions as an "educational medium" that provides a series of aesthetic experiences that have a very large influence on the human soul. [8] Through art education, the internalization of aesthetic experiences will be obtained to train a high sense of taste. With a high sense of taste, children can be easily trained to have religious and moral values. The purpose of holding dance lessons for children with special needs is to increase the development of creativity, sensitivity, and expressiveness.

\subsubsection{Creativity}

Creativity is basically the ability to invent things that have never existed before. Creative activity has a fundamental role and is needed to shape a child's personality. Beside being able to enrich children's mental/inner experiences, creative activity is able to develop children's creativity. With experiences, skills, and imagination, children are expected to act, interpret, organize, and even create something new using a new strategy which leads to different results from what they usually experience daily. Using this strategy, they may become more open, creative, and humane.

\subsubsection{Sensitivity}

Sensitivity is related to responses to certain phenomena. It is only possessed by certain souls and used to express certain feelings. Children with special needs generally have good sensitivity. Thus, it is for them to understand the environment and be touched by a sense of humanity.

\subsubsection{Expressivity}

Expressivity is related to an individual ability to express something. With high awareness, every human will be able to control, even reveal their desired expression. Children with special needs should have a good ability to express their feelings. On the other hand, when they have expressivity, they will be able to actualize themselves according to their personal, will, social and cultural needs. Freedom of expression will encourage children to be open and creative and have good character, morals, and attitudes

\subsection{Special Need Children's Creativity based on the Hyperreality Theory}

Naturally, humans get closer to reality, because they feel uncomfortable with uncertainty or absurdity. Reality is considered as something that provides certainty and is not absurd. Reality refers to what is generally agreed upon as real. Einstein explained that imagination can be more important than knowledge because knowledge is limited to all that we know and understand, while imagination encompasses everything in the world. In addition, all things in the world are possible to be explored and understood using imagination.

The term visual in psychology is the concept of "mental imagery". In general, mental imagery (the variety that is referred to as' visualizing ',' seeing with the mind', 'listening by hearth', 'imagining feelings', etc.) is a quasi-perceptual experience, which resembles a perceptual experience, but occurs without stimulus.

Imagination is different from perception; in that it is under the control of the will and related experiences. For example, children with special needs have the task of making a free dance work according to their imagination. Thus, although the children do not know what an elephant looks like, they will be able to imagine how it looks like and to explore the imagination in dance movement. This means that imagination needs references although it does not have to be precise.

Lacan explained that humans do not adapt themselves to reality. On the contrary, they adapt reality into themselves. This means that the reality that we perceive is adjusted to our knowledge, so children with special needs may understand their imagination both whether it is real and virtual. ${ }^{[9]}$

Being intelligent is when someone can process reality as well as imagine something. In semiotic intelligence and the continuum between real-virtual. Thus, people with a high cultural quotient are those who consciously change their imagination from real to virtual. If someone is trapped in reality, he will be trapped in a life mechanism that eliminates one of the important aspects of humanity, namely "other possibilities". Meanwhile, if someone is trapped in the virtual world, he will become a dreamer. This also applies to children with special needs. [10]

\subsection{The Benefits of Creative Physical Exercise for Children with Special Needs}

Art education is related to aesthetics as well as ethics and logic. Art education develops aesthetic sensitivity and creativity. Lowenfeld argues that the art process helps individuals grow aesthetically, perceptually, intellectually, 
emotionally, creatively, and technically. Art activities can help individuals in this case children with special needs develop their aesthetic, perceptual, intellectual, emotional, and creative senses as well as techniques. [1] Based on the explanation above, children intelligence may be developed optimally in art education [11]

\subsubsection{Physical Development}

In dancing activities, art expressions provide a complete understanding that physical strength is a source of dance movements. In this case, children with special needs are able to develop their coordination in motor movement with a sensibility as a whole (sight, hearing, and taste sensitivity) in a series of events or characters. Through physical development, children with special needs will understand that dancing involves all senses.

\subsubsection{Perception Development}

Creative activity can develop sensory abilities in responding to life experiences through their senses so that the sensitivity can develop properly. Sensitivity serves as the basic ability to learn at school or other places. Besides, using perception, children may get and responses to phenomena.

\subsubsection{Thinking Skill Development}

Art activities can develop children's thinking ability. This is proven by the ability to actualize the knowledge they have by showing interaction with their environment. Through observing/appreciating the surrounding environment or the object being seen, children with special needs will actively develop awareness or critical thinking. Children's critical thinking serves as the basis of learning.

\subsubsection{Emotional Development}

Creative activity, especially dance, consists of controlled or spontaneous emotional expression. It means that the deepest mental symptoms are realized by children is by taking action. Therefore, students who are able to express emotions well will think of ideas openly and flexibly. The emotions of students when trained in controlled and correct ways will develop emotional intelligence. Developing awareness and emotional intelligence is needed in learning activities and self-control.

\subsubsection{Creativity Development}

Creative activity is a manifestation of creativity in art creation. Basically, creativity is very important in the development of science and technology. By developing children's creativity, their talents may be used in learning. By dancing, the children are able to develop their senses and creative thinking ability that help them in learning later.

\subsubsection{Social skill Development}

When dancing, the children can develop their social skills because they interact with other people in their society. Good attitudes and behaviors are built in the dancing process. With certain social skills, the children may accept their conditions as something positive.

\subsubsection{Aesthetic Sense Development}

Creative activity is a process of obtaining aesthetic experience. With the experience, the children are expected to be able to interpret and do something based on aesthetic values and virtuous personalities.

\subsubsection{Talent Development}

Talent is the basic ability that humans are born with. In dancing, the children's talent is shown through their creativity. Using their creativity, children with special needs are expected to be able to motivate them to do physical exercise. In the end, the children tend to choose something that they like. From these phenomena and processes, those children's talents may be observed.

\section{CONCLUSION}

Creativity is an attempt to invent new things based on imagination. Children with special needs have unique physical, mental, and emotional development. In inclusive education, they learn in class along with other children without special needs. This is done to show respect to differences and to let people enjoy their rights to learn and do a creative activity.

Online Learning is one of the methods used to teach children with special needs during the COVID-19 pandemic situation. Children may do physical exercises and use their imagination in choreography as well as experience physical, perception, thinking skill, emotional, creativity, social skill, aesthetic sense, and talent development.

\section{REFERENCES}

[1] Lowenfeld, V. \& Lambert, B., Creative and Mental Growth. New York, MacMillan Co, 1975.

[2] Widiastuti, Erni, "Problematika Guru dalam Pembelajaran Anak Berkebutuhan Khusus (ABK) di Sekolah Inklusi SDN Sumbersari 1 Malang, 2010. [The Problems of Teachers in Learning Children with Special Needs (ABK) at the Inclusive School SDN Sumbersari 1 Malang]." Unpublished.

[3] Hidajat, Robby, "Pengetahuan Seni Tari [Knowledge of Dance]." Malang, Departemen Pendidikan Nasional Universitas Negeri Malang Fakulttas Sastra Jurusan Seni dan Desain, 2004. 
[4] Murgiyanto, Sal, "Koreografi [Choreography].” Jakarta, Pusat Pembukuan Departemen Pendidikan dan Kebudayaan/ PT. Ikrar Mandiri Abadi, 1992.

[5] Ngalimun, dkk, "Perkembangan dan Pengembangan Kreativitas [Development and Development of Creativity]." Yogyakarta, Aswaja Pressindo, 2013.

[6] Hidajat, Robby, "Wawasan Seni Tari. Pengetahuan Praktis Bagi Guru Seni Tari [Dance Arts Insights. Practical Knowledge for Dance Teachers]." Unit Pengembangan Profesi Tari, Program Studi Pendidikan Seni Tari Jurusan Seni dan Desain Fakultas Sastra Universitas Negeri Malang, 2005.

[7] Moleong, L. J, "Metodologi Penelitian Kualitatif (Edisi Revisi) [Qualitative Research Methodology (Revised Edition)]." Bandung, PT Remaja Rosdakarya, 2012.

[8] Sustiawati, Ni Luh. Dkk, "Pengetahuan Tari Bali [Balinese Dance Knowledge]." Denpasar, PT Empat Warna Komunikasi, 2011.

[9] Lacan, Jacques. Ecrits: A Selection, terj. Alan Sheridan. New York\&London, W.W Norton \& Company, 1977.

[10] Piliang, Yasraf Amir \& Audifax, "Kecerdasan Semiotik: Melampaui Dialektika dan Fenomena [Semiotic Intelligence: Beyond Dialectics and Phenomena]." Yogyakarta, Cantrik Pustaka, 2018.

[11] Kamaril, C. "Konsep dan Sistem Pembelajaran Kesenian Terpadu di Sekolah Dasar: Modul 2 [Concepts and Integrated Arts Learning Systems in Elementary Schools: Module 2]." Jakarta, Universitas Terbuka Departemen Pendidikan dan Kebudayaan, 1999. 